\title{
Entrainment by Hydraulic Dredges- A Review of Potential Impacts
}

PURPOSE: This technical note summarizes existing literature regarding potential impacts to aquatic organisms caused by entrainment during dredging and dredged material disposal operations. This information was used to evaluate the current state of knowledge regarding dredge-induced entrainment of commercially and biologically important fish, shellfish, and threatened and endangered species and to identify information gaps where additional research is needed. Specifically, those technical issues related to hypothetical impacts of entrainment that lead to requests for environmental window constraints on dredging operations are given emphasis. Based on the current state of knowledge, future research outlined under the Dredging Operations and Environmental Research (DOER) Program will seek to resolve ambiguity associated with environmental windows linked to entrainment issues and develop operational measures to provide adequate resource protection while maintaining dredging project flexibility.

BACKGROUND/INTRODUCTION: The effects of dredging on aquatic organisms have been a source of environmental concern for several decades. A summary of potential environmental impacts associated with dredging operations can be found in a technical report by LaSalle et al. (1991). One category of concern that has frequently arisen in connection with projects involving hydraulic dredges (e.g., hopper and cutterhead dredges) deals with mortality of fish and shellfish entrained during the dredging process. Entrainment is defined as the direct uptake of aquatic organisms by the suction field generated at the draghead or cutterhead. To a certain degree, this concern is analogous to that of entrainment by power plants withdrawing cooling waters, an issue which has received much scientific and public attention. With respect to entrainment by dredges, several investigations (described below) have sought to determine if absolute entrainment rates and resultant mortalities are meaningful from either broad ecological or fishery population dynamics perspectives. The results of these limited studies have been inconclusive, at least to the extent that findings have seldom been published in the peer-reviewed literature. Thus, the fundamental issues remain subjective. Consequently, state and Federal resource agencies routinely request that dredging operations be restricted when fish or shellfish resources are perceived to be at risk. Entrainment-related restrictions are commonly requested to protect life history stages of many commercially or recreationally important species (e.g., anadromous fishes, oyster larvae), as well as species listed as threatened and/or endangered (e.g., sea turtles).

DREDGING-RELATED ENTRAINMENT: Currently, 49 percent of U.S. Army Corps of Engineers (USACE) Districts (18 districts) report issues related to potential entrainment of aquatic organisms as reasons underlying environmental windows. Entrainment concerns reported in various categories and frequencies by USACE Districts surveyed include: anadromous fishes (19 percent); shellfish (11 percent); and threatened and/or endangered species (32 percent) (Reine, Dickerson, and Clarke 1998). Due to the frequency of entrainment-related issues Corps-wide, an extensive literature review was conducted to examine dredging-related entrainment issues with regard to fish, shellfish, and threatened/endangered species. These studies are summarized with 
respect to the relative degree of susceptibility to entrainment, operational measures to avoid entrainment, and predictive modeling techniques to assess mortality rates and their population level consequences.

Shellfish. Shellfish studies are summarized as follows:

- Dungeness crabs: The Dungeness crab (Cancer magister) is a commercially valuable species found in both marine and estuarine waters from central California northward to southeastern Alaska. While Dungeness crabs are found throughout the estuary, they congregate in navigation channels, particularly during times of low tide or while migrating into or out of the estuary. This affinity for navigation channels renders them susceptible to entrainment during channel dredging operations. Dredge-related entrainment of Dungeness crabs has been studied since the late 1970's. Most entrainment studies involving Dungeness crabs have been conducted in Grays Harbor and Puget Sound, Washington, and include: Tegelberg and Arthur (1977); Stevens (1981); Armstrong, Stevens, and Hoeman (1982, 1987); Dinnel, Armstrong, and Dumbauld (1986); Dinnel et al. (1986); McGraw et al. (1988); Dumbauld et al. (1988); Larson and Patterson (1989); and Wainwright et al. (1990, 1992). Entrainment was examined for hopper, pipeline, and clamshell (although mechanical dredges are not generally treated in an entrainment context) dredging and appears to be a function of the type of dredge used. A variety of factors possibly influencing entrainment rates by dredges include bottom depth, hopper dredge speed or cutterhead rates of advance, flow-field velocities generated at the draghead or cutterhead, volume of dredged material, and direction of dredging with regards to tidal flow. Studies yielded little evidence of bivariate correlation between entrainment and any of the parameters tested with the possible exception of direction of dredging with reference to tidal flow. The later relationship was reported by Larson and Patterson (1989), who recorded highest comparative entrainment rates while dredging against the ebb tide during one series of samples. However, this observation was not duplicated in 3 years of follow-up studies.

- Entrainment rate: While most studies have focused on hopper dredging, clamshell and pipeline dredging operations have also been examined. Armstrong, Stevens, and Hoeman (1982) concluded that a strong probability existed that Dungeness crab populations can be negatively impacted by dredging operations unless proper precautions are taken to reduce losses. Larson and Patterson (1989) also concluded that Dungeness crabs are particularly susceptible to entrainment by hopper dredging in estuaries. Mean entrainment rates (for all hopper dredge studies combined) for adult crabs ranged from 0.040 to 0.592 crabs/cubic yard (cy) of dredged material. Juvenile crabs, especially young-of-theyear crabs ( 7 to $25 \mathrm{~mm}$ ), were entrained at a significantly higher rate (range 0.32 to 10.78 , $\bar{x}=4.14 \mathrm{crabs} / \mathrm{cy}$ ) at an offshore bar station outside Grays Harbor and at the Mouth of the Columbia River (Table 1). Pipeline dredging was also examined by Stevens (1981) and produced an entrainment rate of $0.243 \mathrm{crabs} / \mathrm{cy}$. Clamshell dredging had the least detrimental impacts to Dungeness crabs with "entrainment" rates approximating 0.012 crabs/cy (Table 1). Stevens (1981) stated two possible mitigating factors to account for the reduced mortality by clamshell dredges: avoidance of increased turbidity and suspended sediment concentration as a result of physical disturbance at the bottom; and avoidance of low-frequency vibrations produced from lowering the bucket into the water. These studies indicated that a general linear relationship exists between crab densities and 


\begin{tabular}{|c|c|c|c|c|}
\hline \multicolumn{5}{|c|}{$\begin{array}{l}\text { Table } 1 \\
\text { A summary of Dungeness crab entrainment studies conducted in Grays } \\
\text { Harbor, Washington, and the Columbia River, Washington and Oregon }\end{array}$} \\
\hline Source & Dredge & Study Date & Location & $\begin{array}{l}\text { Entrainment } \\
\text { Rate (crabs/cy) }\end{array}$ \\
\hline \multirow[t]{2}{*}{$\begin{array}{l}\text { Tegelberg and Arthur } \\
1977\end{array}$} & Hopper & Mar 1975 & $\begin{array}{l}\text { Middle and outer } \\
\text { estuary }\end{array}$ & $0.131-0.327$ \\
\hline & Hopper & Mar 1975 & Outer estuary & 0.449 \\
\hline \multirow[t]{5}{*}{ Stevens 1981} & Clamshell & Oct-Dec 1978 & Middle estuary & 0.012 \\
\hline & Hopper & Nov-Dec 1978 & Outer estuary & 0.233 \\
\hline & \multirow[t]{2}{*}{ Pipeline } & Sep-Dec 1979 & Outer estuary & 0.243 \\
\hline & & Nov-Dec 1979 & Inner harbor & 0.0017 \\
\hline & Hopper & Mar 1979 & Outer estuary & 0.182 \\
\hline \multirow{3}{*}{$\begin{array}{l}\text { Armstrong, Stevens, } \\
\text { and Hoeman } 1982\end{array}$} & \multirow[t]{3}{*}{ Hopper } & Jun 1980 & Inner harbor & 0.079 \\
\hline & & Aug 1980 & Middle estuary & 0.107 \\
\hline & & May-Sep 1980 & Middle estuary & 0.075 \\
\hline $\begin{array}{l}\text { Armstrong, Stevens, } \\
\text { and Hoeman } 1987\end{array}$ & Hopper & Oct 1985 & Outer esturary & 0.046 \\
\hline $\begin{array}{l}\text { Dinnel, Armstrong, and } \\
\text { Dumbauld } 1986\end{array}$ & Hopper & Oct 1985 & Outer estuary & 0.118 \\
\hline \multirow[t]{3}{*}{ Dinnel et al. 1986} & \multirow[t]{3}{*}{ Hopper } & \multirow[t]{3}{*}{ Aug 1986} & \multirow[t]{2}{*}{ Outer estuary } & 0.135 \\
\hline & & & & 0.592 \\
\hline & & & Middle estuary & 0.088 \\
\hline \multirow[t]{4}{*}{ McGraw et al. 1988} & \multirow[t]{4}{*}{ Hopper } & \multirow[t]{4}{*}{ Aug 1986} & \multirow[t]{3}{*}{ Outer estuary } & 0.155 \\
\hline & & & & 0.500 \\
\hline & & & & 0.079 \\
\hline & & & Middle estuary & 0.058 \\
\hline \multirow[t]{5}{*}{ Dumbauld et al. 1988} & \multirow[t]{5}{*}{ Hopper } & \multirow[t]{5}{*}{ Aug 1987} & \multirow[t]{4}{*}{ Outer estuary } & 0.222 \\
\hline & & & & 0.397 \\
\hline & & & & 0.133 \\
\hline & & & & 0.224 \\
\hline & & & $\begin{array}{l}\text { Outer estuary } \\
\text { (Bar) }\end{array}$ & 9.367 \\
\hline \multirow{4}{*}{$\begin{array}{l}\text { Larson and Patterson } \\
1989\end{array}$} & \multirow[t]{4}{*}{ Hopper } & Apr-Oct 1985 & \multirow{4}{*}{$\begin{array}{l}\text { Mouth of } \\
\text { Columbia River }\end{array}$} & $10.78(0.04)^{*}$ \\
\hline & & Apr-Oct 1986 & & $1.12(0.08)^{*}$ \\
\hline & & Apr-Oct 1987 & & $3.54(0.18)^{*}$ \\
\hline & & Arp-Oct 1988 & & $0.32(0.03)^{*}$ \\
\hline \multirow[t]{5}{*}{ Wainwright et al. 1990} & \multirow[t]{5}{*}{ Hopper } & \multirow[t]{5}{*}{ Aug 1989} & \multirow[t]{5}{*}{ Outer estuary } & 0.220 \\
\hline & & & & 0.325 \\
\hline & & & & 0.115 \\
\hline & & & & 0.260 \\
\hline & & & & 0.40 \\
\hline
\end{tabular}


entrainment rates. During all studies, entrainment rates for male crabs were twice that for females, probably reflecting female migration out of the estuary before their third year. A summary of relevant data derived from Dungeness crab entrainment studies is given in Table 1.

- Mortality rate: Not all crabs entrained during dredging are killed. Mortality rates were found to depend on dredge type, disposal method, season, crab size, and overall condition of the crab (i.e., degree of softness of the shell as related to molting). Postentrainment mortality resulted from physical trauma, burial or crushing under excessive sediment weight, or disposal into a Confined Disposal Facility (CDF) (Wainwright et al. 1992). Mortality during hopper dredging increased with increasing size, from 5 percent for 7 - to 10 -mm crabs to 86 percent for crabs over $75 \mathrm{~mm}$. Based on limited data, crab mortality rates during clamshell dredging was estimated to be 10 percent for all size classes. When discharge from a pipeline dredging operation occurred directly into a CDF, mortality for all crabs entrained was assumed to be 100 percent. Percent mortality for all age/size classes can be found in Table 2.

- Draghead modification: In a comparison of conventional and modified dragheads on the hopper dredge Yaquina, the modified draghead was ineffective in reducing entrainment of crabs of any size (McGraw et al. 1988). The modified draghead produced an entrainment rate of $0.054 \mathrm{crabs} / \mathrm{cy}$, while the unmodified draghead entrainment rate was $0.064 \mathrm{crabs} / \mathrm{cy}$. Both dragheads cumulatively produced a mean entrainment rate of $0.118 \mathrm{crabs} / \mathrm{cy}$ which was comparable to rates observed in other entrainment studies.

\begin{tabular}{|c|c|c|c|c|}
\hline \multicolumn{5}{|c|}{$\begin{array}{l}\text { Table } 2 \\
\text { Postentrainment mortality rates for Dungeness crab by dredge type, season, } \\
\text { and age class (adapted from Wainwright et al. 1992) }\end{array}$} \\
\hline Dredge Type & Age Class (yr) & Season & $\begin{array}{l}\text { Size Range } \\
(\mathrm{mm})\end{array}$ & Mortality (\%) \\
\hline \multirow[t]{7}{*}{ Hopper } & $0_{+}$ & Apr-May & $7-10$ & 5 \\
\hline & $0_{+}$ & Jun-Sep & $11-30$ & 10 \\
\hline & $0_{+}$ & Oct-Dec & $31-40$ & 20 \\
\hline & $0_{+}$ & Jan-Mar & $41-50$ & 40 \\
\hline & $1+$ & Apr-Sep & $51-75$ & 60 \\
\hline & $1+$ & Oct-Mar & $>75$ & 86 \\
\hline & $>1+$ & All & $>75$ & 86 \\
\hline Clamshell & All & All & All & 10 \\
\hline Pipeline & All & All & All & 100 \\
\hline
\end{tabular}

- Blue crabs: Blue crabs (Callinectes sapidus) are a commercially important resource that supports a large seafood industry in the Chesapeake Bay and along the southeastern Atlantic and Gulf coasts. Blue crabs have been protected by environmental windows in two USACE Districts (USAED), New York and Baltimore, in an attempt to avoid detrimental effects from dredging operations. Due to its commercial value, this species has been studied extensively with regard to spawning, migration, harvesting, and mortality. Blue crabs have been 
speculated to be vulnerable to entrainment during dredging activities, particularly during late fall and winter months when egg-bearing females emigrate to deep water and remain buried in surficial sediments until spring. Overwintering crabs may be too lethargic during this period of inactivity to move out of the path of an approaching dredge. Very few references to dredging-related impacts on blue crabs occur in the scientific literature (Wilber and Clarke in preparation), and no studies were found in the present effort from which entrainment rates could be derived.

- Shrimp: Entrainment of sand shrimp (Crangon spp.) by pipeline and hopper dredges was opportunistically examined during the Dungeness crab studies (Armstrong, Stevens, and Hoeman 1982). Because sand shrimp are important items in the diets of many esturarine organisms, including Dungeness crabs, dredged-related entrainment of large numbers of sand shrimp might reduce their availability as forage (Armstrong, Stevens, and Hoeman 1982). Sand shrimp were the most numerically abundant organism entrained by dredges during the Dungeness crab studies in Pacific northwest estuaries.

Although pink shrimp, (Penaeus duorarum), white shrimp (P. aztecus), and brown shrimp (P. setiferus) are commercially important species along the Gulf and Atlantic coasts and are protected by dredging restrictions to prevent disruption of migration or detrimental impacts to nursery areas, no references were found in the literature regarding potential entrainment effects.

- Entrainment rate: Sand shrimp had the highest rates of entrainment among all organisms during the Dungeness crab studies. Entrainment rates by pipeline dredges were as high as 3.4 shrimp/cy. Entrainment rates by hopper dredges ranged from 0.063 to $3.38 \mathrm{shrimp} / \mathrm{cy}$. Mean entrainment rates for Crangon spp. during pipeline and hopper dredging activities in various locations within Grays Harbor, Washington, can be found in Table 3. Entrainment rates varied significantly during testing of different operating procedures. When pumps were run while the draghead or cutterhead was positioned at or near bottom, the mean entrainment rate was 0.69 shrimp/cy; however, during times when clean water was being pumped to wash out the system and the draghead or cutterhead were not in direct contact with the substrate, the rate of entrainment reached 3.38 shrimp/cy. Based on a calculated annual shrimp population of 80 million, Armstrong, Stevens, and Hoeman (1982) estimated that total loss to the population from entrainment during the course of a "typical" dredging project could range from 1.2 to 6.5 percent.

Bivalves. Bivalve studies are summarized as follows:

- Oysters: Currently only the USAED, Baltimore, has environmental windows to prevent hydraulic entrainment of larval oysters. In the 1980's, entrainment of larval oysters by hydraulic dredges in the Chesapeake Bay was recognized as a potentially important issue. Pelagic, essentially passively drifting larvae of the eastern oyster (Crassostrea virginica), were hypothesized to be at risk of being entrained, particularly by hydraulic pipeline dredges. Entrained larvae are assumed to suffer 100-percent mortality by smothering under sediment, anoxia, starvation, or desiccation, even if they survive the mechanical forces caused by pumping of the water-sediment slurry. A workshop sponsored by the USAED, Baltimore, and the U.S. Army Engineer Waterways Experiment Station (WES) attempted to resolve the issue by assembling experts in oyster biology. Results of the workshop, summarized in the following text, were published in the peer-reviewed literature. 


\begin{tabular}{|c|c|c|c|c|}
\hline $\begin{array}{l}\text { Table } 3 \\
\text { Mean entrainn } \\
\text { activities in G } \\
\text { Hoeman } 1982\end{array}$ & $\begin{array}{l}\text { it rates for } \\
\text { s Harbor, W }\end{array}$ & $\begin{array}{l}\text { gon spp } \\
\text { ngton ( }\end{array}$ & $\begin{array}{l}\text { pipeline an } \\
\text { from Arms }\end{array}$ & $\begin{array}{l}\text { pper dredging } \\
\text {, Stevens, and }\end{array}$ \\
\hline & & & Entrainment & \\
\hline Location & Dredge Type & Total cy & Unadjusted & Adjusted* \\
\hline $\begin{array}{l}\text { Inner harbor } \\
\text { (summer) }\end{array}$ & Pipeline & 357.0 & 3.404 & - \\
\hline $\begin{array}{l}\text { Outer estuary } \\
\text { (winter/spring) }\end{array}$ & Pipeline & 934.5 & 0.001 & - \\
\hline Middle estuary & Hopper & 196.9 & 0.342 & 0.124 \\
\hline Middle estuary & Hopper & 76.3 & 0.063 & 0.079 \\
\hline Middle estuary & Hopper & 273.2 & 0.252 & 0.109 \\
\hline Inner harbor & Hopper & 36.2 & 3.375 & 2.344 \\
\hline $\begin{array}{l}\text { Middle estuary } \\
\text { and inner harbor }\end{array}$ & Hopper & 309.4 & 0.877 & 0.280 \\
\hline Outer estuary & Hopper & 312.9 & 0.260 & 0.232 \\
\hline $\begin{array}{l}{ }^{*} \text { Two entrainmen } \\
\text { on relatively small } \\
\text { entrained. Unadju } \\
\text { Adjusted rates are } \\
\text { 1982). }\end{array}$ & $\begin{array}{l}\text { es are given fo } \\
\text { mples of dredg } \\
\text { d entrainment } v \\
\text { sed on these s }\end{array}$ & $\begin{array}{l}\text { opper dre } \\
\text { diment. Sa } \\
\text { are base } \\
\text { in exces }\end{array}$ & $\begin{array}{l}\text { in estimates of } \\
\text { ess than } 10 \mathrm{cy} \mathrm{ft} \\
\text { nples regardless } \\
\text { (Armstrong, Ste }\end{array}$ & $\begin{array}{l}\text { inment were basec } \\
\text { ntly had no shrimp } \\
\text { tal yards involved. } \\
\text {, and Hoeman }\end{array}$ \\
\hline
\end{tabular}

- Entrainment rate: One product of the oyster larvae entrainment workshop was a numerical model described by Carriker et al. (1986). The model utilizes conservative estimates of larval temporal and spatial distributions and densities, the mechanics and hydrodynamics of dredging operations, and appropriate dimensions of the body of water being dredged. The model predicts that late-stage larvae, which are most likely to be affected, would be entrained at a rate between 0.005 and 0.3 percent of the local population, thus having minimal negative effect. Lunz (1985) reached a conclusion of "no significant impact" from entrainment because the dredge entrains a very small portion of the total water volume flowing past the dredge, and larval oysters suffer a high natural mortality rate (99.999967 percent), thereby making the additional influence of entrainment insignificant. An opposing viewpoint was presented by Carter (1986), who estimated that entrainment mortalities could be as high as 25 percent throughout protracted dredging operations during the oyster spawning season. Both viewpoints are summarized by Presant (1986).

Fishes. Studies of fishes are summarized as follows:

Hydraulic entrainment of fishes has been a concern linked to dredging operations in the United States and elsewhere for several decades. Currently, seven USACE Districts report entrainment as a reason used to justify environmental windows on dredging activities. Species frequently cited include: Gulf and shortnose sturgeon, salmonids, American shad, and winter flounder. One of the 
earliest identified studies of fish entrainment involved juvenile salmon in the lower Fraser River, British Columbia, Canada, which represents a major source of recruitment to Pacific salmon populations (Braun 1974; Dutta and Sookachoff 1975 a, b). Although Braun (1974) found that no salmon fry were entrained by pipeline dredging, Dutta and Sookachoff (1975a) concluded that fry and smolts did suffer high entrainment rates by both pipeline and hopper dredges, particularly when salmon occupied the entire water column in narrow, constricted channels. An additional factor contributing to higher entrainment rates was hypothesized to be the inability of salmon fry and smolts to actively avoid the suction force of hydraulic dredges. Arsenault (1981) estimated that 0.00004 to 0.4 percent of the total out-migration of salmon fry and smolts was entrained by hydraulic dredges. Dutta and Sookachoff (1975a) and Tutty (1976) assessed postentrainment mortality (i.e., at the discharge) to be at or near 100 percent.

In Russia, Veshchev (1981) studied the effects of entrainment on migrating sturgeon larvae (Acipenser guldenstadti and Acipenser stellatus). Details of the type(s) of dredge plants involved were not provided. Veshchev could not find larvae in the discharge flows from the dredge, but calculated entrainment based on the catch of plankton nets placed upstream from the dredge, and thereby produced estimates of mortality as high as 76.8 percent. The sampling methodology was not described in sufficient detail to gauge the appropriate level of confidence that could be placed in these estimates.

Some of the first records of fish entrainment occurred incidentally during Tegelberg and Arthur's (1977) study of entrainment of Dungeness crabs in Grays Harbor, Washington. They observed entrainment of nine fish species, three of which were anadromous. Additionally, Bengston and Brown (1976) observed the entrainment of adult spiny dogfish (Squalus acanthias) during pipeline dredging. While these observations were opportunistic, several studies have since examined the issue in more detail, including Armstrong, Stevens, and Hoeman (1982); McGraw and Armstrong (1990); Larson and Moehl (1990); and Buell (1992).

- Sport and commercial fishes entrainment rate: Entrainment rates for 15 species of sport and commercial fishes were reported by Armstrong, Stevens, and Hoeman (1982) (Table 4). Entrainment rates ranged from 0.001 to 0.135 fish/cy for both pipeline and hopper dredging activities. Both small and large fish were entrained in similar proportions; therefore, it was concluded that large fish did not actively avoid the dredge any more effectively than smaller fish. Entrained fish during this study suffered an initial mortality rate of 37.6 percent. McGraw and Armstrong (1990) collected entrainment information on 28 species of fish during a 10- year period (Table 4). Most species (e.g., slender sole, Lyopsetta exilis) had relatively low absolute entrainment rates approaching $0.001 \mathrm{fish} / \mathrm{cy}$. Species with the highest entrainment rates during this study were the Pacific sanddab (Citharichthys sordidus), Pacific staghorn sculpin (Leptocottus armatus), and the Pacific sand lance (Ammodytes hexapterus) at 0.076, 0.092 and $0.594 \mathrm{fish} / \mathrm{cy}$, respectively. Larson and Moehl (1990) studied fish entrainment during a 4-year study at the mouth of the Columbia River in Oregon. Entrainment rates ranged from $<0.001$ to $0.341 \mathrm{fish} / \mathrm{cy}$ for 14 species or taxonomic groups of fishes (Table 4). The majority of fishes entrained were demersal; however, a few pelagic species were collected, including anchovy, herring, and smelt (Table 4). Entrainment of anadromous fishes 


\begin{tabular}{|c|c|c|c|}
\hline Species & $\begin{array}{l}\text { Hopper }{ }^{1} \\
\text { (fish/cy) }\end{array}$ & $\begin{array}{l}\text { Hopper } 2 \\
\text { (fish/cy) }\end{array}$ & $\begin{array}{l}\begin{array}{l}\text { Pipeline } \\
\text { (fish/cy) }\end{array} \\
\end{array}$ \\
\hline Anchovy (Engraulididae) & 0.008 & 0.001 & - \\
\hline Northern Anchovy (Engraulis mordax) & - & 0.018 & - \\
\hline Herring (Clupeiformes) & 0.008 & - & - \\
\hline Arrowtooth Flounder (Atheresthes stomias) & - & $0.008-0.022$ & - \\
\hline Starry flounder (Platichthys stellatus) & - & $0.001-0.002$ & - \\
\hline English Sole (Pleuronectes vetulus) & - & $0.006-0.035$ & $0.001-0.003$ \\
\hline Sand Sole (Psettichthys melanostictus) & - & $0.001-0.016$ & - \\
\hline Slender Sole (Lyopsetta exilis) & - & 0.001 & - \\
\hline Pacific Sanddab (Citharichthys sordidus) & - & $0.004-0.076$ & - \\
\hline Speckled Sanddab (Citharichthys sordidus) & - & 0.003 & - \\
\hline Flatfish (Pleuronectiformes) & 0.008 & $0.001-0.028$ & - \\
\hline Buffalo Sculpin (Enophrys bison) & - & 0.006 & - \\
\hline Prickly Sculpin (Cottus asper) & - & 0.020 & 0.004 \\
\hline Pacific Staghorn Sculpin (Leptocottus armatus) & 0.003 & $0.007-0.092$ & $0.001-0.037$ \\
\hline Cabezon (Scorpaenichthys marmoratus) & $<0.001$ & - & - \\
\hline Kelp Greenling (Hexagrammos decagrammus) & - & 0.001 & - \\
\hline Lingcod (Ophiodon elongatus) & - & $0.001-0.002$ & - \\
\hline Poacher (Agonidae) & -.009 & - & - \\
\hline Warty Pacher (Occella verrucosa) & - & 0.009 & - \\
\hline Snailfish (Cyclopteridae) & - & 0.001 & - \\
\hline Showy Snailfish (Liparis pulchellus) & 0.002 & - & - \\
\hline Pacific Sandfish (Trichodon trichodon) & $<0.001$ & 0.002 & - \\
\hline Pacific Sand Lance (Ammodytes hexapterus) & 0.341 & $0.036-0.594$ & - \\
\hline Saddleback Gunnel (Pholis ornata) & - & $0.001-0.005$ & 0.023 \\
\hline Snake Prickleback (Lumpenus sagitta) & - & $0.003-0.135$ & - \\
\hline Surfperch (Embiotocidae) & $<0.001$ & 0.001 & - \\
\hline Eulachon (Thaleichthys pacificus) & 0.002 & - & - \\
\hline Chum Salmon (Oncorhynchus keta) & - & - & 0.008 \\
\hline Smelt (Osmeridae) & - & 0.009 & - \\
\hline Pipefish (Syngnathidae) & - & 0.008 & - \\
\hline Bay Pipefish (Syngathus leptorhynchus) & - & 0.006 & - \\
\hline $\begin{array}{l}\text { Three-Spined Stickleback (Gasterosteus } \\
\text { aculeatus) }\end{array}$ & - & - & 0.004 \\
\hline Big Skate (Raja binoculata) & $<0.001$ & - & - \\
\hline Longnose Skate (Raja rhina) & - & 0.003 & - \\
\hline Pacific Tomcod (Microgadus proximus) & $<0.001$ & $0.001-0.008$ & - \\
\hline Spiny Dogfish (Squalus acanthias) & $<0.001$ & - & - \\
\hline
\end{tabular}


was limited to eulachon (Thaleichthys pacificus). Larson and Moehl (1990) concluded that it is unlikely that anadromous fishes are entrained in significant numbers by dredges, at least outside of constricted river areas.

Buell (1992) monitored entrainment by the hydraulic dredge $R$. W. Lofgren by sampling fishes discharged into a containment area and reported that with the exception of white sturgeon (Acipenser transmontanus), entrainment involved small numbers of a few fish species. Although substantial numbers of juvenile white sturgeon were entrained, (size class 300 to $500 \mathrm{~mm}$ ), these were attributed to entrainment at one location referred to as the local "sturgeon hole." The overall rate of entrainment recorded for sturgeon in the Buell (1992) study was $0.015 \mathrm{fish} / \mathrm{cy}$, which is comparable to rates reported for other species of fish.

In the Fraser River, Canada, juvenile salmonids and eulachon were the dominant taxa entrained, whereas at the mouth of the Columbia River and in Grays Harbor, nonanadromous estuarine and marine demersal species were the most frequently entrained (McGraw and Armstrong 1990; Larson and Moehl 1990). One possible explanation in addition to dredge location (the Fraser River site was upstream from the estuary) relates simply to the degree of constriction of the waterway. Juvenile salmon and smelt in the Fraser River case were distributed in closer proximately to the dredge, increasing their relative probabilities of entrainment. In contrast, the mouth of the Columbia River and Grays Harbor are open expanses which allow fish to disperse over a greater area as they migrate through the estuary.

- Modeling-larval fish entrainment: Boreman, Goodyear, and Christensen (1981) developed the Empirical Transport Model (ETM) to estimate the conditional mortality rate of aquatic organisms due to water removal. Burton, Weisberg, and Jacobson (1992) utilized the ETM to simulate a "worst case scenario" of entrainment of striped bass (Morone saxatilis), herring (Alosa spp.), and white perch (Morone americana) larvae involving the simultaneous operation of four hydraulic dredges in the Delaware River. For species such as striped bass, the study concluded that less than 1 percent of the total larval population would be entrained by the dredges. Burton, Weisberg, and Jacobson (1992) concluded that the effects of these entrainment rates on larval populations for these and similar species would be minimal.

Marine turtles. Marine turtles studies are summarized as follows:

- History of dredging effects on sea turtles: Five threatened or endangered species of sea turtles that occur along the southeastern U.S. coast are potentially affected by hopper dredging activities (Dickerson et al. 1995). Sea turtle mortalities due to entrainment during hopper dredging operations have been documented since 1980. The National Marine Fisheries Service (NMFS) determined that, because of their life history and behavioral patterns, only the loggerhead (Caretta caretta), green (Chelonia mydas), and Kemp's ridley (Lepidochelys kempi) are put at risk from hopper dredging (NMFS, Regional Biological Opinion 1995). Early surveys conducted by Butler, Nelson, and Henwood (1987) demonstrated the presence of sea turtles in several channels along the Florida coast. The Endangered Species Observer Program (ESOP), established in 1980, required observers to quantify entrainment of turtles by screening dredged material from hopper dredge intake structures or overflows. In 1981, a Sea Turtle/Dredging Task Force was formally established to address the issue of sea turtle entrainment.

- Entrainment rates: In the decade following the initiation of entrainment monitoring, 174 sea turtles were entrained $(0.91$ turtles/100,000 cy) in dredging operations conducted in 
southeastern U.S. channels (Dickerson et al. 1995). Of these, 159 resulted in mortality, while 15 were classified as live/injured. Entrainment rates ranged from 0.052 turtles/100,000 cy for Brunswick Harbor, Georgia, to 1.68 turtles/100,000 cy for Canaveral Harbor, Florida (Table 5). Canaveral Harbor accounted for 80 percent of all turtle entrainment incidents for the decade with 128 dead and 11 live/injured turtles. Fernandina Harbor, St. Marys River Entrance Channel, Florida, recorded the second highest combined entrainment rate $(0.4$ turtles/100,000 cy), which accounted for 19 percent of the total "take" (29 dead, 2 live/injured). Mean entrainment rates (turtles/100,000 cy) are given by channel dredged and year in Table 5.

From 1990 through 1997, there have been an additional 105 sea turtles entrained. This reflects a significant reduction in the number of turtle entrainment incidents in years subsequent to 1980 when 71 turtles were entrained during dredging in Cape Canaveral Harbor. However, knowledge gained from studies which focused on relative turtle abundance and specific behaviors, as well as engineering studies on draghead modifications, has not entirely eliminated dredge-related sea turtle entrainment. While entrainment rates may be low for several years, periodically there is a substantial increase in the level of entrainment. An example of this occurred in 1991 when Brunswick and Savannah Harbors, Georgia, experienced a dramatic increase in sea turtle entrainment (34 sea turtles) for an entrainment rate of 1.39 turtles/100,000 cy and 1.55 turtles/100,000 cy, respectively. These two harbors had previously shown low entrainment rates of less than 0.11 turtles/100,000 cy and 0.55 turtles/100,000 cy, respectively. The most plausible explanation for this was that dredging occurred during March through June in Brunswick Harbor and June through August in Savannah Harbor when water temperatures were above $25^{\circ} \mathrm{C}$. This may have been above a temperature threshold at which turtles move into nearshore waters.

Sea turtle entrainment rates remained relatively low in most ship channels after the high level reported in 1991 until 1997 when sea turtle entrainment approached the incidental take level established for the southeast region. The highest entrainment rate for the spring of 1997 was obtained during dredging operations conducted in Morehead City Harbor, North Carolina. During this time, six loggerhead turtles were entrained after the removal of only 120,000 cy of sediment. Although the dredge was operating with sea turtle deflecting dragheads, an entrainment rate of 5.0 turtles/100,000 cy occurred, resulting in the termination of the Morehead City Harbor dredging project. Other channels experiencing higher levels of entrainment include: Fernandina Harbor (Kings Bay), Florida (9 turtles entrained), at a rate of 2.06 turtles/100,000 cy; Charleston Harbor (5 turtles entrained), at a rate of 1.43 turtles/ 100,000 cy; and Savannah Harbor (3 turtles entrained), at a rate of 0.55 turtles/100,000 cy. In 1997, a total of 28 loggerhead sea turtle entrainment incidents had occurred during hopper dredging activities (Table 5). Contributing factors for these high entrainment rates appear to be an early and unusually high abundance of sea turtles in nearshore and inshore waters; and the reduced efficiency of the draghead deflector under certain dredging conditions.

- Sea turtle entrainment by species: By species, loggerheads were the most frequently entrained during hopper dredging, accounting for 67.4 percent of the total entrainment (for turtles identified per species). Green sea turtles and Kemp's ridleys accounted for 11.1 and 2.5 percent of entrainment incidents, respectively. Nineteen percent were unidentified as to species, since only fragments were recovered. Assuming that the majority of unidentified entrained turtles were loggerheads, the overall entrainment rate for this species could account for as much as 86.4 percent of the total. 


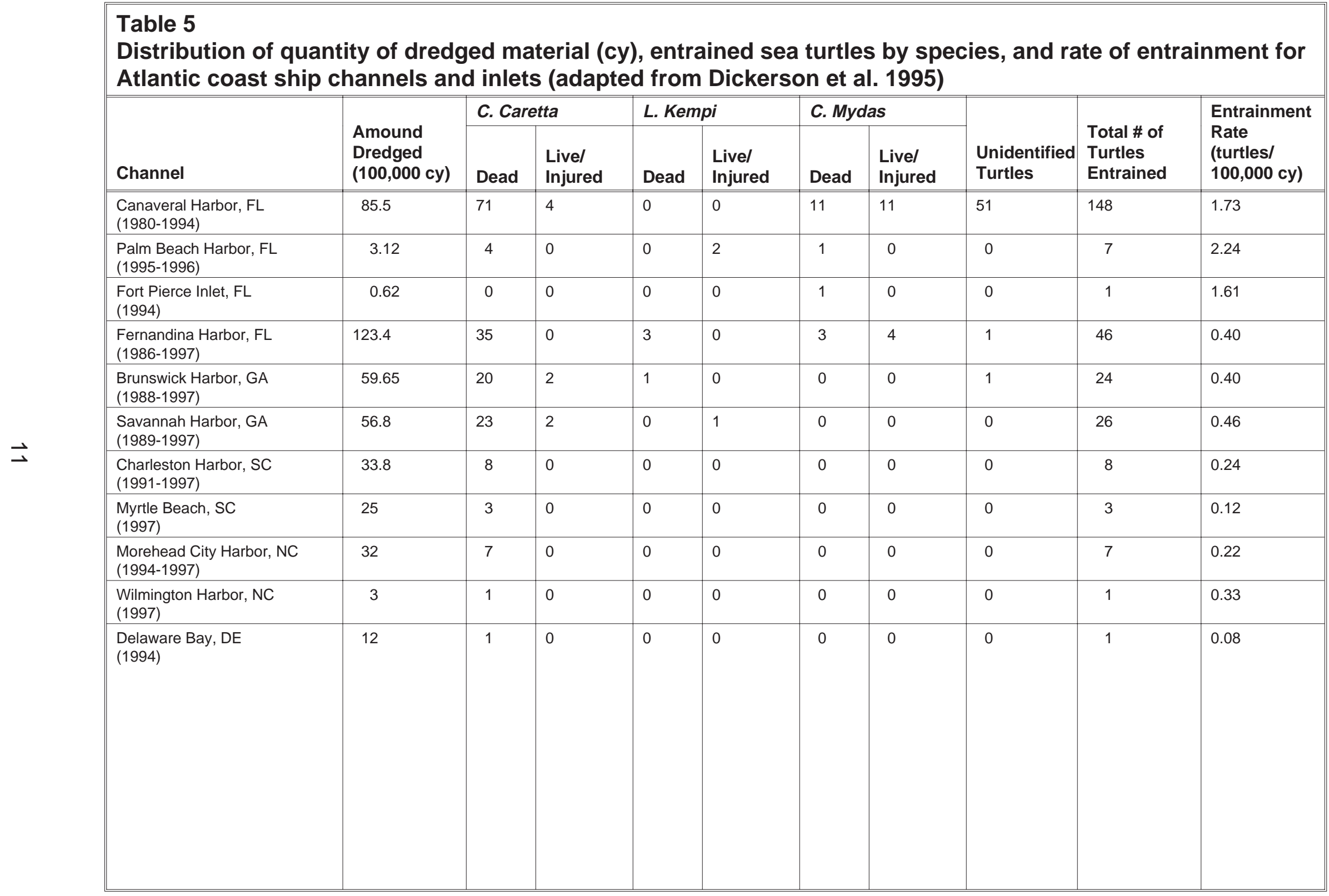


SUMMARY: Effects of entrainment by hydraulic dredging operations on aquatic organisms have been and continue to be an issue of environmental concern. Clearly, assessment of actual impacts due to entrainment pose severe technical challenges. Studies to date illustrate the difficulties in determining precise estimates of absolute entrainment rates and have seldom been able to determine population-level consequences with any degree of confidence. Placing mortalities due to entrainment by dredges into a fishery population dynamic framework, such that dredging can be viewed within the context of other anthropogenic and natural sources of mortality for a resource, would enhance the ability to balance needs for resource protection and dredging project schedules. The persistent lack of quantitative data characterizing effects of entrainment hampers efforts to resolve the issue as it applies to environmental windows. Much of the available evidence suggests that entrainment is not a significant problem for many species of fish and shellfish in many bodies of water that require periodic dredging. Also, many dredging restrictions are based upon limited scientific data, suggesting that well-designed studies and new assessment tools are needed to remove entrainment issues from the realm of subjectivity. In the same regard, however, certain types of dredging operations appear to pose sufficient risk to sensitive resources such that continued application of restrictions is justified. Notably, these exceptions include the conduct of dredging operations in narrow constricted river channels, particularly where sturgeon may be present in appreciable numbers or in channels seasonally occupied by sea turtles or other protected species. Additional studies are definitely warranted to establish the necessity of entrainment-related environmental windows for these resources of concern.

POINTS OF CONTACT: Contact the authors, Mr. Kevin J. Reine (601-634-3436, reinek @mail.wes.army.mil) or Dr. Douglas G. Clarke (601-634-3770, clarked@mail.wes.army.mil), Coastal Ecology Branch, Environmental Resources Division, Environmental Laboratory, or the managers of the Dredging Operations and Environmental Research Program, Mr. E. Clark McNair (601-634-2070,mcnairc@mail.wes.army.mil) or Dr. Robert M. Engler (601-634-3624,englerr@ mail.wes.army.mil). This technical note should be cited as follows:

Reine, K., and Clarke, D. (1998). "Entrainment by hydraulic dredges-A review of potential impacts." Technical Note DOER-E1. U.S. Army Engineer Research and Development Center, Vicksburg, MS.

\section{REFERENCES}

Armstrong, D., Stevens, B., and Hoeman, J. (1982). "Distribution and abundance of Dungeness crab and Crangon shrimp, and dredged-related mortality of invertebrates and fish in Grays Harbor, Washington." Technical Report. School of Fisheries, University of Washington, Washington Department of Fisheries, and U.S. Army Engineer District, Seattle.

. (1987). "Model of dredging impact on Dungeness crab in Grays Harbor, Washington," Fisheries Research Institute Report FRI-UW-8702, School of Fisheries, University of Washington, Seattle.

Arsenault, J. (1981). “Dredge Monitoring Program-1980,” Memorandum No. 5902-121-50-2, Field Services Branch, Environment Canada, Vancouver.

Bengston, C., and Brown, J. (1976). "Impact of dredging on the fishes in Grays Harbor, Appendix G: Maintenance dredging and the environment of Grays Harbor, WA," U.S. Army Engineer District, Seattle. 
Boreman, J., Goodyear, C., and Christensen, S. (1981). "An empirical transport methodology for estimating entrainment losses at power plants sited on estuaries," Transactions of the American Fisheries Society (110), 253-260.

Braun, F. (1974). "Monitoring the effects of hydraulic suction dredging on migrating fish in the Fraser River. Phases I and II," Department of Public Works, Canada.

Buell, J. (1992). "Fish entrainment monitoring of the Western-Pacific Dredge R. W. Lofgren during operations outside the preferred work period," prepared for the Western-Pacific Dredging Company by Buell and Associates, Inc., Portland, OR.

Burton, W., Weisberg, S., and Jacobson, P. (1992). "Entrainment effects of maintenance hydraulic dredging in the Delaware River Estuary on Striped Bass Ichthyoplankton," report submitted to the Delaware Basin Fish and Wildlife Management Cooperative, Trenton, NJ, by Versar, Inc.

Butler, R., Nelson, W., and Henwood, T. (1987). "A trawl survey method for estimating loggerhead turtle, Caretta caretta, abundance in five eastern Florida channels and inlets," Fishery Bulletin 85 (3), 447-53.

Carriker, M., LaSalle, M., Mann, R., and Pritchard, D. (1986). "Entrainment of oyster larvae by hydraulic cutterhead dredging operations: Workshop conclusions and recommendations." Entrainment of Larval Oysters, American Malacological Bulletin Special Edition (3), 71-4.

Carter, W. R. (1986). "An argument for retaining periods of non-dredging for the protection of oyster resources in upper Chesapeake Bay." Entrainment of Larval Oysters, American Malacological Bulletin Special Edition (3), 5-10.

Dickerson, D., Reine, K., Nelson, D., and Dickerson, C., Jr. (1995). “Assessment of sea turtle abundance in six south Atlantic U.S. channels," Miscellaneous Paper EL-95-5, U.S. Army Engineer Waterways Experiment Station, Vicksburg, MS.

Dinnel, P., Armstrong, D., and Dumbauld, B. (1986). "Impact of dredging and dredged material disposal on Dungeness crab, Cancer magister, in Grays Harbor, Washington, during October, 1985," final report, FRI-UW-8606, to the U.S. Army Engineer District, Seattle.

Dinnel, P., Armstrong, D., Dumbauld, B., and Wainwright, T. (1986). "Impact of dredging on Dungeness crab, Cancer magister, in Grays Harbor, Washington, during August 1986," Fisheries Research Institute Report FRI-UW-8611, University of Washington, Seattle.

Dumbauld, B., Armstrong, D., Dinnel, P., and Wainwright, T. (1988). "Impact of dredging on Dungeness crab, Cancer magister, in Grays Harbor, Washington, during August 1987," Fisheries Research Institute Report FRI-UW-8820, University of Washington, Seattle.

Dutta, L., and Sookachoff, P. (1975a). "Assessing the impact of a 24" suction pipeline dredge on chum salmon fry in the Fraser River," Environment Canada, Pacific and Yukon Region, Fisheries and Marine Service Technical Report No. PAC/T-75-26.

. (1975b). "A review of suction dredge monitoring in the Lower Fraser River, 1971-1975," Environment Canada, Pacific and Yukon Region, Fisheries and Marine Service Technical Report No. PAC/T-75-27.

Larson, K., and Moehl, C. (1990). "Fish entrainment by dredges in Grays Harbor, Washington." Effects of dredging on anadromous Pacific Coast fishes. C. A. Simenstad, ed., Washington Sea Grant Program, University of Washington, Seattle, 102-12.

Larson, K., and Patterson, K. (1989). "Entrainment of Dungeness crab by hopper dredge at the mouth of the Columbia River, OR, and WA, USA." Dredging: Proceedings of WODCON XII. Orlando, FL, 268-85.

LaSalle, M., Clarke, D., Homziak, J., and Fredette, J. (1991). "A framework for assessing the need for seasonal restrictions on dredging and disposal operations," Technical Report D-91-1, U.S. Army Engineer Waterways Experiment Station, Vicksburg, MS.

Lunz, J. (1985). “An analysis of available information concerning the entrainment of oyster larvae during hydraulic cutterhead dredging operations with commentary on the reasonableness of seasonally restrictive dredging windows." U.S. Army Engineer Waterways Experiment Station, Vicksburg, MS (prepared in response to a request for assistance through the Dredging Operations Technical Support (DOTS) Program). 


\section{Technical Note DOER-E1}

December 1998

McGraw, K., and Armstrong, D. (1990). "Fish entrainment by dredges in Grays Harbor, Washington." Effects of dredging on anadromous Pacific Coast fishes. C. A. Simenstad, ed., Washington Sea Grant Program, University of Washington, Seattle.

McGraw, K., Conquest, L., Waller, J., Dinnel, P., and Armstrong, D. (1988). "Entrainment of Dungeness crabs, Cancer magister Dana, by hopper dredge in Grays Harbor, Washington," Journal of Shellfish Research 7(2), 219-31.

National Marine Fisheries Service, Regional Biological Opinion. (1995). "Dredging of channels in the southeastern United States from North Carolina through Cape Canaveral, Florida," Southeast Regional Office, St. Petersburg, FL.

Presant, R. (1986). "Entrainment of larval oysters by hydraulic cutterhead dredges: An introduction," Entrainment of Larval Oysters, American Malacological Bulletin, Special Edition (3), 1-4.

Reine, K., Dickerson, D., and Clarke, D. (1998). "Environmental windows associated with dredging operations in aquatic systems." Technical Note DOER-E2, U.S. Army Corps of Engineers, Environmental Laboratory, Vicksburg, MS.

Stevens, B. (1981). "Dredging related mortality of Dungeness crabs associated with four dredges operating in Grays Harbor, Washington," Washington Department of Fisheries Report to U.S. Army Engineers District, Seattle, WA.

Tegelberg, H., and Arthur, R. (1977). "Distribution of Dungeness crabs (Cancer magister) in Grays Harbor and some effects of channel maintenance dredging, Appendix N: Maintenance dredging and the environment of Grays Harbor, Washington," Washington Department of Fisheries Report to U.S. Army Engineers District, Seattle, WA.

Tutty, B. (1976). "Assessment of techniques used to quantify salmon smolt entrainment by a hydraulic suction hopper dredge in the Fraser River Estuary," Environment Canada, Pacific and Yukon Region, Fisheries and Marine Service Technical Report No. PAC/T-76-16.

Veshchev, P. (1981). "Effect of dredging operations in the Volga River on migration of sturgeon larvae," Journal of Ichthyology 21(5), 108-12.

Wainwright, T., McGraw, K., Armstrong, D., Dumbauld, B., and Conquest, L. (1990). "Impact of dredging on Dungeness crab, Cancer magister, in Grays Harbor, Washington, during August 1989," Fisheries Research Institute Report UW-FRI-9005, University of Washington, Seattle.

Wainwright, T., Armstrong, D., Dinnel, P., Orensanz, J., and McGraw, K. (1992). "Predicting effects of dredging on a crab population: An equivalent adult loss approach," Fishery Bulletin (90), 171-82.

Wilber, D., and Clarke, D. (in preparation). "Sediment resuspension during dredging operations: Impacts to fish and shellfish,” U.S. Army Corps of Engineers, Environmental Laboratory, Vicksburg, MS. 